\title{
Cellular modelling of Alström syndrome in human primary dermal fibroblasts and derived cells
}

\author{
RK Semple $1^{*}$, J-H Chen ${ }^{1}$, RB Paisey ${ }^{2}$, TG Barrett ${ }^{3}$, M Hales $^{4}$ \\ From First International Cilia in Development and Disease Scientific Conference (2012) \\ London, UK. 16-18 May 2012
}

\begin{abstract}
Alström syndrome (AS) is a complex disorder whose manifestations include retinal degeneration, sensorineural hearing loss, cardiomyopathy, liver fibrosis, and severe insulin resistance. It is caused by biallelic loss-of-function mutations in the ALMS1 gene, encoding a large centrosomal protein of poorly understood function. Although the syndrome encompasses several cardinal features of ciliopathies, primary cilia have been reported to be morphologically normal in primary cells from patients with AS. In order to dissect out the cellular pathology of AS in humans we have now, in a project led by Alström UK, assembled a bank of dermal fibroblasts from patients with AS. All 11 cell lines studied to date show normal primary cilia on serum starvation. 3/11 lines express near normal levels of ALMS1 protein at the centrosome despite biallelic ALMS1 mutations, which will permit refinement of existing genotype-phenotype correlations in AS. We have also generated induced pluripotent stem cells that will be differentiated into cell types relevant to the organ-specific pathologies of AS including cardiomyocytes, hepatocytes and adipocytes. Finally we have used lentivirally-mediated expression of the adipose differentiation regulator PPARgamma2 to reprogramme human dermal fibroblasts to adipocytes. We have developed a highly efficient protocol to produce cells that accumulate triglyceride, show a pattern of gene expression consistent with adipocytes, secrete adiponectin and leptin, and respond physiologically to insulin. Collectively these developments constitute a valuable cellular resource for studying the cellular pathology of AS, and may form the basis of preclinical treatment screens in future.
\end{abstract}

* Correspondence: rks16@cam.ac.uk

${ }^{1}$ University of Cambridge, UK

Full list of author information is available at the end of the article

\section{Author details}

${ }^{1}$ University of Cambridge, UK. ${ }^{2}$ Torbay Hospital, UK. ${ }^{3}$ Birmingham University, UK. ${ }^{4}$ Alström, UK.

Published: 16 November 2012

doi:10.1186/2046-2530-1-S1-P102

Cite this article as: Semple et al:: Cellular modelling of Alström

syndrome in human primary dermal fibroblasts and derived cells. Cilia 2012 1(Suppl 1):P102.
Submit your next manuscript to BioMed Central and take full advantage of:

- Convenient online submission

- Thorough peer review

- No space constraints or color figure charges

- Immediate publication on acceptance

- Inclusion in PubMed, CAS, Scopus and Google Scholar

- Research which is freely available for redistribution
C Biomed Central
C Biomed Central

(C) 2012 Semple et al; licensee BioMed Central Ltd. This is an Open Access article distributed under the terms of the Creative Commons Attribution License (http://creativecommons.org/licenses/by/2.0), which permits unrestricted use, distribution, and reproduction in any medium, provided the original work is properly cited. 